\title{
Households, poverty and policy in times of crisis. Mexico, 1992-1996
}

\author{
Benjamin Davis, Sudhanshu Handa and Humberto Soto
}

Benjamín Davis

Economist,

United Nations Food and

Agriculture Organization/ESA

- benjamin.davis@fao.org

Sudhanshu Handa

Associate Professor,

Department of Public Policy, University of North Carolina

- shanda@mail.unc.edu

Humberto Soto

Research Associate,

Department of Economics,

Universidad Iberoamericana,

Mexico City

- humberto.soto@uia.mx efore the 1995 crisis, Mexico had registered over a decade of improvements in human development indicators. Using decomposition techniques, this paper measures the benefits of those improvements in terms of allowing households to cope with that crisis. The decline in consumption between 1994 and 1996 is amply explained by the reduction in the returns to household characteristics, with the changes in those characteristics serving to reduce the negative impact of the crisis. Had household characteristics remained at their 1992 levels, rural poverty in 1996 would have been $48 \%$ higher than observed. The results of our simulation show that had the PROGRESA programme been in place during the crisis, the rural poverty gap and the squared poverty gap would have been reduced. The conclusion is that social programmes that focus on long term development can also perform an important safety net function during a macroeconomic crisis. 
I

\section{Introduction}

In 1995 Mexico sustained one of its worst economic crises in recent history, with per capita GDP falling by $9 \%$ and real wages by $25 \%$. Yet this crisis was preceded by over a decade of growth in social and economic indicators and important changes in the structure of the economy. On the eve of the crisis, Mexico was clearly a different society than 10 years earlier. How did these long-term changes in Mexican society influence the ability of Mexican households to withstand the crisis and, ultimately, to recover from it? In answering this question, we return to the core issue of 'growth versus development' which has preoccupied the development community since the early 1980s. During the five years before the peso crisis, Mexico's GDP increased by an average of $3 \%$ per year, but even more importantly, this period of growth was accompanied by an even longer period of development, as manifested by reductions in infant mortality and increased access to education, as well as structural changes in the economy. Our goal is to quantify the impact of this 'development' in ameliorating the negative consequences of the macro crisis of 1995. By doing so, we contribute to the state of knowledge on the trade-offs involved in pursuing development strategies that focus on narrowly defined economic growth, in contrast with strategies that pursue growth and development objectives together.

The paper begins with a description of the
Mexican crisis and a review of the country's performance in terms of poverty, growth and social indicators. We then analyze the behavioral response of households to the macroeconomic shock of 1995. This is followed by a decomposition, using standard techniques, of the changes in consumption between 1992, 1994 and 1996, distinguishing between changes due to differences in the environment and institutions, and changes due to differences in the characteristics of households. Finally, we explore the role that social programmes can play in mitigating and alleviating poverty during macroeconomic crises, using two of Mexico's larger social programmes as our examples _ the Direct Support Programme for Rural Areas (PROCAMPO) and the Education, Health and Food Programme (PROGRESA), now called the "Oportunidades" programme.

Our analysis is based on household data from three successive (1992, 1994, and 1996) National Income and Expenditure Surveys (ENIGH) carried out by the Mexican government's statistical institute, INEGI (National Institute of Statistics, Geography and Information Processing). These are not panel data surveys but rather repeated cross-sectional surveys which cover all forms of income and expenditures. The 1994 survey was carried out prior to the crisis, so that the impact of this exogenous shock can be captured by comparing the 1994 and 1996 surveys.

\footnotetext{
$\square$ The authors wish to express their gratitude for the valuable observations of Marco Stampini, Gabriel Demombynes, Daniel Hérnandez, Oscar Altimir, and an anonymous referee. We also wish to thank Emmanuel Skoufias for helping to construct the consumption aggregates and Susan Parker for the information provided. We also wish to pay tribute to José Gómez de Léon (1946-2000), who made some observations on an earlier version of this study and with whom we had the honour of working on the PROGRESA programme.
} 


\section{II}

\section{Economic reform and crisis}

During the presidency of Carlos Salinas de Gortari (1988-1994), Mexico embarked upon a programme of structural economic reforms. These reforms were a response to the series of economic crises that had hit the Mexican economy since 1976, as well as to the import substitution development strategy that had been followed in Mexico in previous decades. The government signed the General Agreement on Tariffs and Trade (GATT); entered into the North American Free Trade Agreement (NAFTA) with Canada and the United States; privatized most State enterprises; initiated changes in the system of land ownership in the ejido (land reform) sector through the reform of Article 27 of the Constitution, affecting over half of Mexican territory; and modified the role of the State in credit, marketing, and other support services to agriculture.

An overvalued exchange rate and reliance on volatile short-term foreign investment led to a severe foreign exchange crisis during the first year of the Administration of President Ernesto Zedillo (19942000). The crisis resulted in a heavy devaluation
(120\% between December 1994 and March 1995), high levels of inflation and skyrocketing real interest rates, and macroeconomic instability through 1996. Real GDP dropped over 6\% in 1995 (8.6\% in per capita terms), as the economy entered a severe repression. By the next year, the economy had bounced back with 5\% growth (almost 3\% in per capita terms). Despite the rebounding economy, however, average daily real wages dropped 24\% between 1994 and 1996 (after having risen $21 \%$ between 1992 and 1994), and remained essentially the same in 1997 (Banco de México, 1999; INEGI, 1999).

The crisis had a more severe effect on wage income than non-wage income, which resulted in urban areas being harder hit by the ensuing fall in consumption. While monthly per capita consumption fell in rural areas by $4 \%$, it fell by a stunning $27 \%$ in urban areas between 1994 and 1996. The concomitant increases in extreme and moderate poverty rates were more than three times higher in urban areas then rural areas. We discuss these changes in more detail below.

TABLE 1

Mexico: Poverty incidence, by relative poverty line, 1992, 1994 and 1996

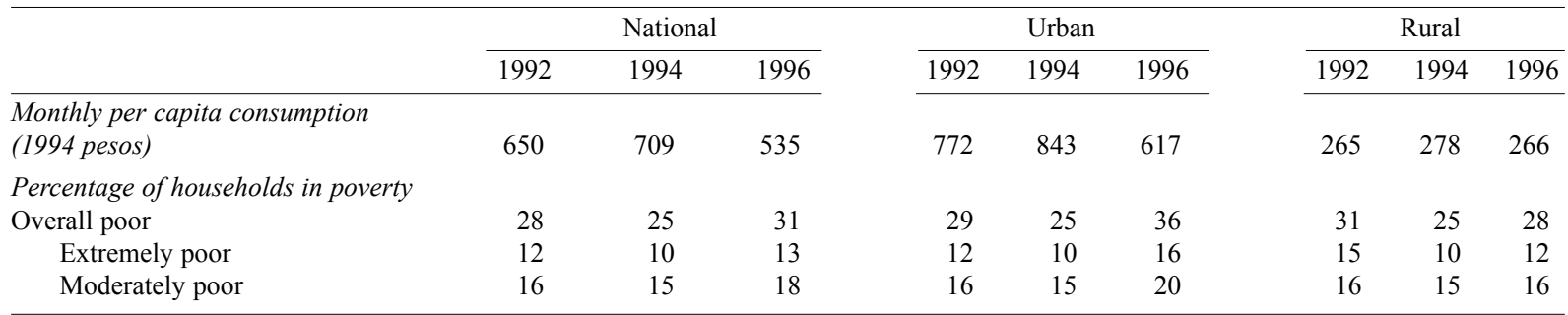

Source: Prepared by the authors on the basis of the National Household Income and Expenditure Surveys (ENIGH) for 1992,1994 and 1996.

TABLE 2

Mexico: Percentage change in incidence of poverty, by relative poverty line, 1992, 1994 and 1996

\begin{tabular}{|c|c|c|c|c|c|c|}
\hline & \multicolumn{2}{|c|}{ National } & \multicolumn{2}{|c|}{ Urban } & \multicolumn{2}{|c|}{ Rural } \\
\hline & 1992-94 & $1994-96$ & $1992-94$ & $1994-96$ & $1992-94$ & 1994-96 \\
\hline $\begin{array}{l}\text { Monthly per capita consumption (1994 pesos) } \\
\text { Percentage of households in poverty }\end{array}$ & 9 & -25 & 9 & -27 & 5 & -4 \\
\hline Percentage of households in poverty & & & & & & \\
\hline Overall poor & -11 & 23 & -13 & 43 & -20 & 13 \\
\hline Extremely poor & -18 & 27 & -18 & 61 & -35 & 21 \\
\hline Moderately poor & -5 & 21 & -9 & 31 & -5 & 8 \\
\hline
\end{tabular}

Source: Prepared by the authors on the basis of the National Household Income and Expenditure Surveys (ENIGH) for 1992, 1994 and 1996. 
The government found it difficult to protect those affected by the crisis, due to fiscal constraints. Between 1994 and 1995, government social spending dropped 12\% in real terms (Lustig and Székely, 1998), though some emergency safety net programmes, such as temporary work programmes, were enacted. Instead, the government tightened monetary and fiscal policies and continued the structural adjustment of the economy.

\section{Long-term trends of social indicators}

Mexico has made tremendous progress over the last few decades in terms of improving the wealth and living standards of its population. Since 1950, real per capita GDP has almost doubled, the proportion of illiterate adults has fallen from $45 \%$ to $11 \%$, and the proportion of adults completing primary school has risen from $10 \%$ to $70 \%$. Infant mortality has fallen from 178 out of 1000 live births in 1930 to 30.5 in 1995, and over the same period child mortality has fallen from 156 per 1000 to 4.4 per thousand. By 1997, over $85 \%$ of the population had access to potable water (CONAPO, 1997).

The overall improvement in social and demographic indicators masks significant regional variations, however. Men residing in Oaxaca, for example, on average live 4.7 years less than in Nuevo León (CONAPO, 1997). Similarly, the rates of infant mortality in Oaxaca, Chiapas and Guerrero are more than double that of Mexico City, Nuevo León and Baja California. Confounding the national trend, the rate of child mortality in Guerrero has actually increased from 36.7 per thousand in 1992 to 63.8 per thousand in 1997. Similar large differences in rates are found when comparing urban and rural areas and when taking into account the age or educational status of the mother (Programa Nacional de Acción a favor de la Infancia, 1998).

While overall adult illiteracy stood at $11 \%$ in 1997, the figure varied from less than $4 \%$ in Mexico City and Nuevo León to over $20 \%$ in Chiapas, Guerrero, and Oaxaca. The proportion of residents with access to potable water in that year ranged from 99\% in Sonora to less than $70 \%$ in Veracruz, Guerrero, Tabasco, Chiapas and Oaxaca. Similarly, while $99 \%$ of residents of Colima had access to sewerage services, less than 50\% had such access in Yucatán, Guerrero and Oaxaca (Programa Nacional de Acción a favor de la Infancia, 1998).

Poverty rates, not surprisingly, have followed similar trends. Lustig and Székely (1998) reviewed estimates of poverty rates made by a collection of researchers for the 1960s and 1970s, and while most disagreed on the levels of poverty, all found that poverty rates dropped over this period. Hernández Laos (1990) found that extreme poverty fell from 70\% in 1963 to 34\% in 1977, while Székely (1998) found a drop from $30 \%$ to $18 \%$ over the same period.

According to Lustig and Székely (1998), both extreme and moderate poverty, as well as inequality, increased between 1984 and 1989. Little change in national poverty and inequality indicators was found between 1989 and 1994. Again, however, these national figures mask regional variations, as the southern region showed a large increase in the number of poor. As shown in their study and in our data below, poverty is particularly concentrated in the southern region of Mexico.

\section{III}

\section{The changing characteristics of the poor, 1992 to 1996}

Our hypothesis is that the nature of the 1994-1995 crisis led to a change in the characteristics of households living in poverty, as determined by a consumptionbased welfare measure. Given the sharp impact of the crisis on interest rates and real wages, we would expect middle and working class households to have the sharpest drops in consumption levels. The ranks of the poor would thus be enlarged through the addition of households with relatively higher levels of education, an older demographic structure, and other indicators of greater long-term well-being. We find that while on average the characteristics of the poor evolve 
as hypothesized, at the margin these same characteristics, such as household education levels, play an even greater role in reducing the probability of a family falling into poverty.

\section{The increase in poverty}

Using consumption as the basic welfare measure will almost invariably lead to the conclusion that the proportion of households living in poverty in Mexico increased between 1994 and 1996, given the drop in per capita consumption observed over this period. Wide divergences exist, however, among government and international agencies as to the appropriate poverty line, consequently leading to widely varying estimates as to the number of poor in Mexico. ${ }^{1}$ Since our objective is to analyze changes in consumption and poverty between 1992 and 1996, and not to enter into the debate as to the precise number of poor in Mexico, we have chosen as poverty lines, for the purposes of this study, the consumption level corresponding to the 10th percentile in 1994 as the extreme poverty line, and the consumption level corresponding to the 25 th percentile in 1994 as the moderate poverty line.

Using constant 1994 prices, we can compare changes in the index of the number of poor across time, and these are reported in tables 1 and 2 . Under our definition, 1994 (prior to the shock) appears to have been a positive year in terms of poverty reduction. In both urban and rural areas, the average monthly per capita level of consumption increased between 1992 and 1994, while the proportion of households under the poverty line fell. These gains, however, were more than wiped out between 1994 and 1996, particularly in urban areas, as we mentioned earlier. The proportion of urban households in extreme poverty increased over $60 \%$ and the proportion in moderate poverty increased $30 \%$.

\footnotetext{
1 While estimates of the incidence of poverty vary, in general the trends over time are similar: falling poverty rates until 1994, with a spike upward in 1996 due to the crisis, followed by a gradual decline. See, for example, ECLAC (2002).
}

\section{Poverty profiles}

Table 3 shows the mean values for a variety of household characteristics by year, location, and poverty status. Here we find evidence for our hypothesis that the crisis hit relatively better-off families, resulting in a change in the overall characteristics of poor households. Thus, we find an improvement in the characteristics of extremely and moderately poor households, particularly from 1994 to 1996 . The urban poor are increasingly better educated, have higher levels of ownership of consumer durables such as stereos, refrigerators and VCRs, have fewer small children, and there is a lower proportion of households with dirt floors. Likewise, in 1996 the rural poor show greater ownership of consumer durables, a lower proportion of households with dirt floors, and an improvement in levels of education among family members.

Probit equations were estimated to determine the probability of a household being poor (combining extreme and moderate poverty) for all three years, by urban and rural areas. The results are presented in tables 4 and 5. We find that while the average effects reflect the changing overall characteristics of the poor, at the margin in 1996 higher levels of education, for example, had an even stronger effect on reducing the probability of living in poverty. Similarly, while poor households, particularly those in urban areas, on average have increasingly fewer children over time, additional children and adolescents significantly increased the probability of living in poverty in 1996 .

The role played by labour activities remained relatively constant: in both urban and rural areas nonagricultural wage labour was associated with a lower probability of living in poverty, while the opposite was true for agricultural wage labour. The sign for selfemployment activities switched between years, however: for urban households, in 1992 and 1996 selfemployment was associated with a high probability of living in poverty, while the reverse was true for 1994. Overall, the results for 1996 show that younger families with greater numbers of children and adolescents, with lower levels of education among both household heads and non-heads, and living in the Pacific South (and for urban households in the Gulf region as well) were much more likely to fall into poverty. 
TABLE 3

Mexico: Characteristics of poor households in urban and rural areas, 1992, 1994 and 1996

\begin{tabular}{|c|c|c|c|c|c|c|c|c|c|}
\hline & \multicolumn{3}{|c|}{ Extremely poor } & \multicolumn{3}{|c|}{ Moderately poor } & \multicolumn{3}{|c|}{ Non poor } \\
\hline & 1992 & 1994 & 1996 & 1992 & 1994 & 1996 & 1992 & 1994 & 1996 \\
\hline \multicolumn{10}{|l|}{ Urban areas } \\
\hline Number of members without primary education & 1.14 & 1.21 & 0.95 & 0.71 & 0.86 & 0.57 & 0.32 & 0.32 & 0.24 \\
\hline Number of members with primary education & 0.81 & 0.71 & 0.83 & 0.75 & 0.84 & 0.61 & 0.46 & 0.43 & 0.35 \\
\hline Number of members with secondary or technical education & 0.55 & 0.45 & 0.68 & 0.73 & 0.75 & 0.90 & 0.85 & 0.90 & 0.88 \\
\hline Number of members with higher education & 0.03 & 0.02 & 0.03 & 0.05 & 0.04 & 0.09 & 0.24 & 0.25 & 0.30 \\
\hline Number of family members aged 0 to 4 & 0.95 & 1.05 & 0.94 & 0.65 & 0.80 & 0.58 & 0.39 & 0.39 & 0.35 \\
\hline Share of households with stereo & 0.23 & 0.14 & 0.20 & 0.27 & 0.21 & 0.33 & 0.57 & 0.52 & 0.51 \\
\hline Share of households with VCR & 0.09 & 0.10 & 0.11 & 0.20 & 0.22 & 0.25 & 0.50 & 0.51 & 0.50 \\
\hline Share of households with refrigerator & 0.28 & 0.32 & 0.42 & 0.56 & 0.57 & 0.68 & 0.85 & 0.85 & 0.87 \\
\hline Share of households with dirt floor & 0.28 & 0.26 & 0.21 & 0.13 & 0.13 & 0.07 & 0.03 & 0.03 & 0.02 \\
\hline Number of observations & 704 & 722 & 1404 & 950 & 1081 & 1721 & 4116 & 5405 & 5610 \\
\hline \multicolumn{10}{|l|}{ Rural areas } \\
\hline Number of members without primary education & 1.65 & 1.62 & 1.70 & 1.45 & 1.44 & 1.36 & 0.98 & 0.96 & 0.80 \\
\hline Number of members with primary education & 0.39 & 0.59 & 0.67 & 0.56 & 0.60 & 0.72 & 0.59 & 0.57 & 0.57 \\
\hline Number of members with secondary or technical education & 0.08 & 0.13 & 0.16 & 0.20 & 0.17 & 0.27 & 0.38 & 0.37 & 0.47 \\
\hline Number of members with higher education & 0.00 & 0.00 & 0.00 & 0.00 & 0.00 & 0.00 & 0.01 & 0.02 & 0.03 \\
\hline Number of family members aged 0 to 4 & 1.38 & 1.36 & 1.47 & 0.98 & 0.95 & 0.99 & 0.59 & 0.56 & 0.53 \\
\hline Share of households with stereo & 0.01 & 0.02 & 0.04 & 0.06 & 0.05 & 0.12 & 0.15 & 0.15 & 0.17 \\
\hline Share of households with VCR & 0.00 & 0.02 & 0.01 & 0.02 & 0.02 & 0.04 & 0.10 & 0.11 & 0.13 \\
\hline Share of households with refrigerator & 0.02 & 0.04 & 0.05 & 0.11 & 0.10 & 0.17 & 0.34 & 0.36 & 0.42 \\
\hline Share of households with dirt floor & 0.76 & 0.75 & 0.69 & 0.66 & 0.53 & 0.48 & 0.34 & 0.28 & 0.25 \\
\hline Number of observations & 605 & 482 & 539 & 620 & 721 & 723 & 2712 & 3604 & 3191 \\
\hline
\end{tabular}

Source: Prepared by the authors on the basis of the National Household Income and Expenditure Surveys (ENIGH) for 1992. 1994 and 1996.

HOUSEHOLDS, POVERTY AND POLICY IN TIMES OF CRISIS. MEXICO, 1992-1996 • BENJAMIN DAVIS, SUDHANSHU HANDA AND HUMBERTO SOTO 
Mexico: Probit estimate of probability of living in poverty (extreme and moderate combined), urban households, 1992, 1994 and $1996^{a}$

\begin{tabular}{|c|c|c|c|c|c|c|}
\hline \multirow{2}{*}{ 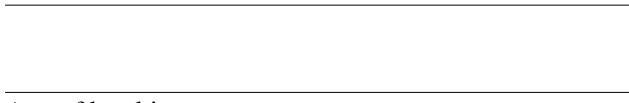 } & \multicolumn{2}{|c|}{1992} & \multicolumn{2}{|c|}{1994} & \multicolumn{2}{|c|}{1996} \\
\hline & coeff & $\mathrm{P}>|\mathrm{z}|$ & coeff & $\mathrm{P}>|\mathrm{z}|$ & coeff & $\mathrm{P}>|\mathrm{z}|$ \\
\hline Age of head in years & 0.001 & 0.40 & -0.001 & 0.43 & -0.002 & $0.02 * *$ \\
\hline Female head of household & 0.001 & 0.98 & -0.026 & 0.11 & -0.011 & 0.61 \\
\hline Ln (household size) & 0.296 & $0.00 * * *$ & 0.137 & $0.00 * * *$ & 0.181 & $0.00 * * *$ \\
\hline Head has some primary education & -0.089 & $0.00 * * *$ & -0.078 & $0.00 * * *$ & -0.119 & $0.00 * * *$ \\
\hline Head has complete primary education & 0.139 & $0.00 * * *$ & -0.124 & $0.00 * * *$ & -0.227 & $0.00 * * *$ \\
\hline Head has some secondary education & -0.182 & $0.00 * * *$ & -0.171 & $0.00 * * *$ & -0.288 & $0.00 * * *$ \\
\hline Head has some vocational or technical education & 0.209 & $0.00 * * *$ & -0.183 & $0.00 * * *$ & -0.334 & $0.00 * * *$ \\
\hline Head has some higher education & -0.265 & $0.00 * * *$ & -0.234 & $0.00 * * *$ & -0.407 & $0.00 * * *$ \\
\hline No. of members without primary education & -0.011 & 0.48 & 0.056 & $0.00 * * *$ & 0.080 & $0.00 * * *$ \\
\hline No. of members with complete primary education & 0.041 & $0.01 * * *$ & 0.008 & 0.51 & 0.022 & 0.18 \\
\hline No. of members with secondary or technical education & -0.088 & $0.00 * * *$ & -0.053 & $0.00 * * *$ & -0.062 & $0.00 * * *$ \\
\hline No. of members with some higher education & -0.152 & $0.00 * * *$ & -0.114 & $0.00 * * *$ & -0.172 & $0.00 * * *$ \\
\hline Dependency ratio of households ${ }^{b}$ & 0.353 & $0.00 * * *$ & 0.064 & 0.13 & 0.215 & $0.00 * * *$ \\
\hline No. of household members aged $0-4$ & 0.043 & $0.00 * * *$ & 0.075 & $0.00 * * *$ & 0.121 & $0.00 * * *$ \\
\hline No. of household members aged 5-10 & 0.010 & 0.38 & 0.058 & $0.00 * * *$ & 0.087 & $0.00 * * *$ \\
\hline No. of male household members aged 11-14 & 0.011 & 0.47 & 0.044 & $0.00 * * *$ & 0.089 & $0.00 * * *$ \\
\hline No. of female household members aged 11-14 & -0.008 & 0.58 & 0.027 & $0.03 * *$ & 0.105 & $0.00 * * *$ \\
\hline No. of male household members aged 15-19 & 0.067 & $0.00 * * *$ & 0.030 & $0.02 * *$ & 0.096 & $0.00 * * *$ \\
\hline No. of female household members aged 15-19 & 0.060 & $0.00 * * *$ & 0.053 & $0.00 * * *$ & 0.075 & $0.00 * * *$ \\
\hline No. of male household members aged 20-34 & 0.047 & $0.00 * * *$ & 0.020 & $0.05 * *$ & 0.058 & $0.00 * * *$ \\
\hline No. of female household members aged 20-34 & 0.037 & $0.00 * * *$ & 0.003 & 0.75 & 0.031 & $0.02 * *$ \\
\hline No. of male household members aged 55 or more & 0.029 & 0.18 & -0.007 & 0.66 & 0.014 & 0.53 \\
\hline No. of female household members aged 55 or more & 0.039 & $0.04 * *$ & -0.016 & 0.26 & 0.029 & 0.11 \\
\hline No. of non-agricultural wage earners & -0.007 & 0.54 & -0.027 & $0.01 * * *$ & -0.032 & $0.02 * *$ \\
\hline No. of agricultural wage earners & 0.064 & $0.01 * * *$ & 0.080 & $0.00 * * *$ & 0.062 & $0.03 * *$ \\
\hline No. of self-employed & 0.051 & $0.00 * * *$ & -0.031 & $0.01 * * *$ & 0.029 & $0.07 *$ \\
\hline No. of own farm workers & 0.019 & 0.33 & -0.010 & 0.45 & -0.058 & $0.00 * * *$ \\
\hline Own house & -0.076 & $0.00 * * *$ & -0.053 & $0.00 * * *$ & -0.054 & $0.01 * * *$ \\
\hline Rented house & -0.134 & $0.00 * * *$ & -0.082 & $0.00 * * *$ & -0.140 & $0.00 * * *$ \\
\hline Head of family works in agricultural sector & 0.129 & $0.00 * * *$ & 0.063 & $0.02 * *$ & 0.138 & $0.00 * * *$ \\
\hline Head of family works in manufacturing & 0.051 & $0.05 * *$ & -0.026 & 0.18 & 0.105 & $0.00 * * *$ \\
\hline Head of family works in transport/utilities/commerce & 0.033 & 0.14 & -0.010 & 0.56 & 0.093 & $0.00 * * *$ \\
\hline Head of family works in government or defence sector & 0.032 & 0.28 & -0.038 & $0.08 *$ & 0.032 & 0.27 \\
\hline Head works in services sector & 0.028 & 0.27 & -0.022 & 0.23 & 0.109 & $0.00 * * *$ \\
\hline North & -0.111 & $0.00 * * *$ & -0.051 & $0.02 * *$ & -0.064 & $0.01 * * *$ \\
\hline Pacific North & -0.155 & $0.00 * * *$ & -0.110 & $0.00 * * *$ & -0.162 & $0.00 * * *$ \\
\hline Central & -0.059 & $0.01 * * *$ & -0.043 & $0.04 * *$ & -0.049 & $0.03 * *$ \\
\hline Gulf & -0.101 & $0.00 * * *$ & -0.014 & 0.53 & 0.017 & 0.52 \\
\hline Urban metropolitan area & -0.191 & $0.00 * * *$ & -0.142 & $0.00 * * *$ & -0.148 & $0.00 * * *$ \\
\hline Number of observations & & 5723 & & 7145 & & 8678 \\
\hline
\end{tabular}

Source: Prepared by the authors on the basis of the National Household Income and Expenditure Surveys (ENIGH) for 1992.1994 and 1996.

a Coefficients are marginal probabilities derived from Probit coefficients. "No education" is the excluded category for head's education. $* * *$ significant at $1 \%$.

** significant at $5 \%$.

* significant at $10 \%$.

b Dependency rate of households corresponds to the ratio of the number of employed persons in the household to the total number of persons in the household. 
TABLE 5

Mexico: Probit estimate of probability of living in poverty (extreme and moderate combined), rural households, 1992,1994 and $1996^{\mathrm{a}}$

\begin{tabular}{|c|c|c|c|c|c|c|}
\hline & \multicolumn{2}{|c|}{1992} & \multicolumn{2}{|c|}{1994} & \multicolumn{2}{|c|}{1996} \\
\hline & coeff & $\mathrm{P}>|\mathrm{z}|$ & coeff & $\mathrm{P}>|\mathrm{z}|$ & coeff & $\mathrm{P}>|\mathrm{z}|$ \\
\hline Age of head in years & 0.000 & 0.90 & -0.001 & 0.19 & -0.002 & $0.03 * *$ \\
\hline Female head of household & 0.018 & 0.59 & 0.034 & 0.17 & 0.005 & 0.85 \\
\hline Ln (household size) & 0.201 & $0.00 * * *$ & 0.207 & $0.00 * *$ & 0.111 & $0.02 * *$ \\
\hline Head has some primary education & -0.094 & $0.00 * * *$ & -0.042 & $0.00 * * *$ & -0.031 & 0.06 \\
\hline Head has complete primary education & -0.131 & $0.00 * * *$ & -0.084 & $0.00 * * *$ & -0.099 & $0.00 * * *$ \\
\hline Head has some secondary or some higher education & -0.178 & $0.00 * * *$ & -0.121 & $0.00 * * *$ & -0.146 & $0.00 * * *$ \\
\hline No. of members without primary education & 0.001 & 0.94 & 0.14 & 0.25 & 0.037 & $0.02 * *$ \\
\hline No. of members with complete primary education & -0.068 & $0.00 * *$ & -0.023 & $0.07 *$ & -0.027 & 0.10 \\
\hline No. of members with secondary or technical education & -0.081 & $0.00 * * *$ & -0.068 & $0.00 * * *$ & -0.080 & $0.00 * * *$ \\
\hline No. of members with some higher education & -0.189 & 0.03 & -0.170 & 0.02 & -0.339 & $0.01 * * *$ \\
\hline Dependency ratio of households ${ }^{b}$ & 0.243 & $0.00 * * *$ & 0.039 & 0.46 & 0.209 & $0.00 * * *$ \\
\hline No. of household members aged $0-4$ & 0.042 & $0.00 * * *$ & 0.038 & $0.00 * * *$ & 0.085 & $0.00 * * *$ \\
\hline No. of household members aged 5-10 & 0.031 & $0.01 * * *$ & 0.021 & $0.01 * * *$ & 0.057 & $0.00 * * *$ \\
\hline No. of male household members aged 11-14 & -0.014 & 0.35 & 0.016 & 0.15 & 0.030 & $0.04 * *$ \\
\hline No. of female household members aged 11-14 & 0.023 & 0.13 & 0.013 & 0.25 & 0.030 & $0.04 * *$ \\
\hline No. of male household members aged 15-19 & 0.014 & 0.47 & 0.009 & 0.54 & 0.044 & $0.02 * *$ \\
\hline No. of female household members aged 15-19 & 0.017 & 0.38 & -0.020 & 0.18 & 0.031 & $0.08 *$ \\
\hline No. of male household members aged 20-34 & 0.009 & 0.56 & 0.018 & 0.12 & 0.028 & $0.05 * *$ \\
\hline No. of female household members aged 20-34 & 0.002 & 0.92 & -0.010 & 0.38 & 0.010 & 0.51 \\
\hline No. of male household members aged 55 or more & -0.017 & 0.47 & -0.007 & 0.66 & 0.005 & 0.83 \\
\hline No. of female household members aged 55 or more & 0.027 & 0.21 & 0.010 & 0.51 & 0.004 & 0.84 \\
\hline No. of non-agricultural wage earners & -0.009 & 0.53 & -0.062 & $0.00 * * *$ & -0.044 & $0.00 * * *$ \\
\hline No. of agricultural wage earners & 0.028 & $0.02 * *$ & 0.008 & 0.51 & 0.027 & $0.04 * *$ \\
\hline No. of self-employed & 0.071 & $0.00 * * *$ & -0.002 & 0.89 & 0.006 & 0.69 \\
\hline No. of own farm workers & 0.028 & $0.03 * *$ & -0.003 & 0.79 & 0.003 & 0.79 \\
\hline Own house & 0.011 & 0.63 & 0.034 & 0.04 & 0.066 & $0.00 * * *$ \\
\hline Rented house & -0.076 & 0.30 & -0.079 & 0.18 & -0.037 & 0.56 \\
\hline Head of family works in agricultural sector & 0.070 & $0.02 * *$ & 0.002 & 0.92 & 0.019 & 0.48 \\
\hline Head of family works in manufacturing & 0.029 & 0.50 & -0.001 & 0.97 & -0.012 & 0.74 \\
\hline Head of family works in transport/utilities/commerce & -0.041 & 0.22 & -0.071 & $0.00 * * *$ & -0.031 & 0.31 \\
\hline Head of family works in government or defence sector & -0.037 & 0.50 & -0.072 & $0.05 * *$ & -0.069 & 0.11 \\
\hline Head works in services sector & -0.035 & 0.43 & -0.074 & $0.01 * * *$ & -0.007 & 0.86 \\
\hline North & -0.063 & $0.00 * * *$ & -0.079 & $0.00 * * *$ & -0.109 & $0.00 * * *$ \\
\hline Pacific North & -0.121 & $0.00 * * *$ & -0.083 & $0.00 * * *$ & -0.123 & $0.00 * * *$ \\
\hline Central & -0.061 & $0.00 * * *$ & -0.041 & $0.01 * * *$ & -0.050 & $0.01 * * *$ \\
\hline Gulf & -0.074 & $0.00 * * *$ & -0.008 & 0.66 & -0.035 & $0.07 *$ \\
\hline Number of observations & & 3927 & & 4801 & & 4438 \\
\hline
\end{tabular}

Source: Prepared by the authors on the basis of the National Household Income and Expenditure Surveys (ENIGH) for 1992,1994 and 1996.

a Coefficients are marginal probabilities derived from Probit coefficients. "No education" is the excluded category for head's education.

*** significant at $1 \%$.

** significant at $5 \%$.

* $\quad$ significant at $10 \%$.

b Dependency rate of households corresponds to the ratio of the number of employed persons in the household to the total number of persons in the household. 


\section{IV}

\section{Behavioral responses to the crisis}

In order to understand how households adjusted during the 1995 crisis, we explored whether significant changes in food and general consumption patterns occurred during the period studied. We also analyzed school enrolment rates to see if households systematically removed children from school to help with shortterm income earning activities.

\section{Consumption patterns}

Consumption patterns were explored in four different ways, each exploiting the details of the ENIGH consumption questionnaire. We first analyzed changes in expenditure shares in major consumption groups to see whether there was significant consumption switching among expenditure groups in response to the overall decline in welfare in 1995 . Next we calculated the income effects for budget shares, using Engel curve regression equations. We then repeated these two exercises considering only food budget shares.

The Engel curve regression equations are based on the Working-Leser functional form where the budget share is regressed against log total per capita expenditure, log of household size, the number of people in each of 12 sex-specific age groups, and the sex, schooling and age of the household head: ${ }^{2}$

$w_{i}=a+b_{1} * \ln (x / n)+b_{2}{ }^{*} \ln (\mathrm{n})+b_{3}{ }^{*} D+b_{4}{ }^{*} H+u_{i}[1]$

where $w_{i}$ is the $i$ th budget share, $x$ is total household expenditure, $n$ is household size, $D$ is a vector of 12 demographic variables, $H$ is a vector of household head characteristics, and $a$ and $b_{i}$ are parameters to be estimated. In this form, positive values of $b$ indicate luxury goods, and negative values necessities.

We begin our discussion of consumption patterns with the proportion of the overall consumption bundle allocated to 10 different groups, shown in percentage terms for the three survey years in table 6, which also shows the budget shares for the bottom quintile of the per capita expenditure distribution for each year. The same pattern of consumption switching was observed for urban and rural areas between 1994 and 1996. The food share rose by roughly five percentage points in the year after the crisis, while the shares devoted to housing, alcohol and domestic goods (furniture, appliances, etc.) fell. There was also a small decline in the budget shares of clothing in both urban and rural areas. A worrying trend is the decline in the share of education between 1994 and 1996. In rural areas the share of the budget devoted to educational expenses was over $50 \%$ less in 1996, and in urban areas the drop was approximately $25 \%$.

Among the poorest quintile, as might be expected, the overall share devoted to food is higher, and the changes in the shares between 1994 and 1996 mirror those found in the full sample. The food share rose by seven percentage points in rural areas (five in urban), with declines in the alcohol, housing, and domestic budget shares. The worrying decline in allocations to education is especially large in this sub-sample, with drops equivalent to $70 \%$ (rural) and $50 \%$ (urban) relative to the 1994 levels.

Table 7 shows the coefficient of log per capita expenditure calculated from equation [1]. Both the rural and urban estimates of income effects show that food and housing are unambiguously necessities, while education, health and hygiene, transportation, domestic items, and transfers out are unambiguously luxuries. The coefficient for food rose significantly (in absolute value) in 1996, as expected, while the coefficients for transportation, clothing, and health also rose in 1996, indicating that they became more of a luxury good. Housing became more 'luxurious' in 1996 in both urban and rural areas, while in rural areas the jump between 1994 and 1996 for transportation and communication and for clothing was especially large.

2 See Deaton and Muellbauer (1980) for a discussion of this functional form.

HOUSEHOLDS. POVERTY AND POLICY IN TIMES OF CRISIS. MEXICO. 1992-1996 • BENJAMIN DAVIS. SUDHANSHU HANDA AND HUMBERTO SOTO 
Mexico: Mean household budget shares of various expenditure categories, rural and urban areas

(Percentages)

\begin{tabular}{|c|c|c|c|c|c|c|}
\hline & \multicolumn{3}{|c|}{ Total population } & \multicolumn{3}{|c|}{ Bottom quintile } \\
\hline & 1992 & 1994 & 1996 & 1992 & 1994 & 1996 \\
\hline \multicolumn{7}{|l|}{ Rural areas } \\
\hline Food & 46 & 42 & 47 & 51 & 47 & 54 \\
\hline Alcohol and tobacco & 0 & 3 & 0 & 0 & 1 & 0 \\
\hline Housing & 17 & 23 & 22 & 18 & 27 & 25 \\
\hline Transport and communication & 7 & 7 & 7 & 3 & 4 & 3 \\
\hline Health and personal hygiene & 6 & 7 & 8 & 4 & 5 & 5 \\
\hline Clothing and footwear & 8 & 5 & 5 & 10 & 5 & 4 \\
\hline Education & 2 & 3 & 1 & 2 & 3 & 1 \\
\hline Domestic items & 9 & 8 & 7 & 8 & 7 & 6 \\
\hline Transfers out & 1 & 1 & 1 & 0 & 0 & 0 \\
\hline Other & 5 & 1 & 2 & 4 & 0 & 2 \\
\hline Number of observations & 3911 & 4797 & 4442 & 665 & 823 & 814 \\
\hline \multicolumn{7}{|l|}{ Urban areas } \\
\hline Food & 35 & 32 & 36 & 44 & 42 & 46 \\
\hline Alcohol and tobacco & 0 & 2 & 0 & 0 & 1 & 0 \\
\hline Housing & 22 & 28 & 26 & 20 & 26 & 24 \\
\hline Transport and communication & 8 & 9 & 10 & 6 & 7 & 8 \\
\hline Health and personal hygiene & 6 & 7 & 8 & 6 & 7 & 7 \\
\hline Clothing and footwear & 5 & 5 & 4 & 6 & 4 & 4 \\
\hline Education & 5 & 5 & 4 & 5 & 5 & 2 \\
\hline Domestic items & 9 & 7 & 6 & 8 & 7 & 6 \\
\hline Transfers out & 2 & 1 & 1 & 0 & 0 & 0 \\
\hline Other & 8 & 3 & 4 & 6 & 1 & 3 \\
\hline Number of observations & 5739 & 7199 & 8709 & 1193 & 1491 & 1979 \\
\hline
\end{tabular}

Source: Prepared by the authors on the basis of the National Household Income and Expenditure Surveys (ENIGH) for 1992,1994 and 1996.

The income elasticity for food is lower in urban areas, as is the elasticity of transport and health and personal hygiene. However, all these elasticities increased in absolute terms between 1994 and 1996. One important difference between rural and urban areas is that the income elasticity of education is much larger (almost double) in urban areas. Hence educational expenditures are more sensitive to income in urban than in rural areas in Mexico.

Table 8 shows the mean values of food budget shares over the three time periods under study. There is less switching among food groups than between food and the other broad groups, but some basic patterns emerge. Over $40 \%$ of the food budget in rural areas is devoted to cereals and to fruits, vegetables and legumes, and in the bottom quintile these groups account for around 60\% of the food budget. During the crisis, households generally responded by increasing the share allocated to cereals and dairy products and reducing expenditures on meat and fish and 'other' foods.
The same shift is observed in urban areas, although here cereals rank only fourth in importance in the food budget, while meat and fish and 'food eaten out' are the two largest food groups, accounting for over $40 \%$ of the entire food budget. Urban households in the bottom quintile have food consumption patterns more similar to those of the rural population as a whole, with over $40 \%$ of the budget dedicated to cereals and to vegetables, fruits and legumes.

Table 9 gives estimates of the income elasticities for each food group by year and region, using equation [1]. For both urban and rural areas, cereals, vegetables, and other foods were unambiguous necessities, while food eaten out was a luxury. However, meat and fish were a luxury in rural areas only, while dairy products were a necessity in urban areas. Between 1994 and 1996, income elasticities increased (in absolute terms) for cereals and vegetables (i.e., they became more of a necessity), while other foods become more of a luxury (income elasticity increased). Surprisingly, the income elasticity for food eaten out declined in 1996. 
TABLE 7

\begin{tabular}{|c|c|c|c|}
\hline \multicolumn{4}{|c|}{ Mexico: Income effects for full household budget shares ${ }^{a}$} \\
\hline & 1992 & 1994 & 1996 \\
\hline \multicolumn{4}{|l|}{ Rural areas } \\
\hline Food & $\begin{array}{l}-4.07 \\
(9.82)\end{array}$ & $\begin{array}{c}-5.73 \\
(15.87)\end{array}$ & $\begin{array}{c}-6.55 \\
(16.24)\end{array}$ \\
\hline Alcohol and tobacco & $\begin{array}{c}0.06 \\
(1.09)\end{array}$ & $\begin{array}{c}2.14 \\
(10.52)\end{array}$ & $\begin{array}{c}0.05 \\
(0.92)\end{array}$ \\
\hline Housing & $\begin{array}{c}-3.35 \\
(12.18)\end{array}$ & $\begin{array}{c}-6.95 \\
(22.33)\end{array}$ & $\begin{array}{c}-5.43 \\
(17.74)\end{array}$ \\
\hline Transport and communication & $\begin{array}{c}3.73 \\
(17.16)\end{array}$ & $\begin{array}{c}1.94 \\
(9.66)\end{array}$ & $\begin{array}{c}3.66 \\
(17.55)\end{array}$ \\
\hline Health and personal hygiene & $\begin{array}{c}2.18 \\
(10.81)\end{array}$ & $\begin{array}{c}2.50 \\
(11.54)\end{array}$ & $\begin{array}{c}3.31 \\
(15.40)\end{array}$ \\
\hline Clothing and footwear & $\begin{array}{l}-1.48 \\
(7.77)\end{array}$ & $\begin{array}{c}0.51 \\
(3.61)\end{array}$ & $\begin{array}{c}0.92 \\
(6.89)\end{array}$ \\
\hline Education & $\begin{array}{c}0.45 \\
(3.95)\end{array}$ & $\begin{array}{c}0.69 \\
(5.80)\end{array}$ & $\begin{array}{c}0.68 \\
(9.13)\end{array}$ \\
\hline Domestic items & $\begin{array}{c}1.25 \\
(5.45)\end{array}$ & $\begin{array}{c}1.76 \\
(9.22)\end{array}$ & $\begin{array}{c}0.53 \\
(3.70)\end{array}$ \\
\hline Transfers out & $\begin{array}{c}0.96 \\
(9.98)\end{array}$ & $\begin{array}{c}2.11 \\
(16.19)\end{array}$ & $\begin{array}{c}1.83 \\
(14.57)\end{array}$ \\
\hline Other & $\begin{array}{c}0.28 \\
(2.23)\end{array}$ & $\begin{array}{c}1.04 \\
(11.40)\end{array}$ & $\begin{array}{c}1.01 \\
(7.65)\end{array}$ \\
\hline \multicolumn{4}{|l|}{ Urban areas } \\
\hline Food & $\begin{array}{c}-8.04 \\
(27.82)\end{array}$ & $\begin{array}{c}-8.65 \\
(37.21)\end{array}$ & $\begin{array}{c}-9.26 \\
(38.35)\end{array}$ \\
\hline Alcohol and tobacco & $\begin{array}{c}0.04 \\
(1.54)\end{array}$ & $\begin{array}{c}1.12 \\
(8.05)\end{array}$ & $\begin{array}{l}-0.01 \\
(0.25)\end{array}$ \\
\hline Housing & $\begin{array}{l}-1.30 \\
(5.07)\end{array}$ & $\begin{array}{c}-2.99 \\
(11.09)\end{array}$ & $\begin{array}{l}-1.56 \\
(6.75)\end{array}$ \\
\hline Transport and communication & $\begin{array}{c}1.16 \\
(7.36)\end{array}$ & $\begin{array}{c}0.81 \\
(5.82)\end{array}$ & $\begin{array}{c}1.19 \\
(8.44)\end{array}$ \\
\hline Health and personal hygiene & $\begin{array}{c}1.12 \\
(8.42)\end{array}$ & $\begin{array}{c}1.78 \\
(10.87)\end{array}$ & $\begin{array}{c}2.41 \\
(15.65)\end{array}$ \\
\hline Clothing and footwear & $\begin{array}{c}0.38 \\
(3.60)\end{array}$ & $\begin{array}{c}0.22 \\
(2.43)\end{array}$ & $\begin{array}{c}0.61 \\
(7.78)\end{array}$ \\
\hline Education & $\begin{array}{c}1.30 \\
(8.45)\end{array}$ & $\begin{array}{c}1.75 \\
(11.96)\end{array}$ & $\begin{array}{c}1.94 \\
(17.96)\end{array}$ \\
\hline Domestic items & $\begin{array}{c}2.09 \\
(11.54)\end{array}$ & $\begin{array}{c}1.69 \\
(11.38)\end{array}$ & $\begin{array}{c}0.65 \\
(6.73)\end{array}$ \\
\hline Transfers out & $\begin{array}{c}1.89 \\
(17.93)\end{array}$ & $\begin{array}{c}1.30 \\
(14.41)\end{array}$ & $\begin{array}{c}1.36 \\
(16.37)\end{array}$ \\
\hline Other & $\begin{array}{c}1.37 \\
(8.46)\end{array}$ & $\begin{array}{c}2.96 \\
(27.26)\end{array}$ & $\begin{array}{c}2.66 \\
(23.18)\end{array}$ \\
\hline
\end{tabular}

Source: Prepared by the authors on the basis of the National Household Income and Expenditure Surveys (ENIGH) for 1992,1994 and 1996.

a Figures correspond to coefficients for log per capita expenditure derived from Engel curve estimates using equation [1] in the text. $t$-statis tics are shown in parenthesis below coefficients. Negative coefficients imply necessities, positive coefficients imply luxury items.

\section{School enrolment}

The ENIGH data set provides very little information on individual welfare outcomes such as health or nutrition. Information on educational attainment, however, including current school enrolment, provides an additional insight into the possible coping strategies of Mexican households. In general, enrolment rates are high $(90 \%)$ until the end of primary school, and begin to fall around age 11 . We therefore focus on children 12-15 years old, analyzing enrolment patterns to see if the 1995 crisis had any significant impact on possible long-term development through declines in school enrolment rates.

HOUSEHOLDS. POVERTY AND POLICY IN TIMES OF CRISIS. MEXICO. 1992-1996 • BENJAMIN DAVIS. SUDHANSHU HANDA AND HUMBERTO SOTO 
Mexico: Mean shares of different expenditure items in household food budget (Percentages)

\begin{tabular}{|c|c|c|c|c|c|c|}
\hline & \multicolumn{3}{|c|}{ Total population } & \multicolumn{3}{|c|}{ Bottom quintile } \\
\hline & 1992 & 1994 & 1996 & 1992 & 1994 & 1996 \\
\hline \multicolumn{7}{|l|}{ Rural areas } \\
\hline Cereals & 24 & 23 & 24 & 34 & 31 & 34 \\
\hline Meat and fish & 14 & 16 & 15 & 8 & 12 & 10 \\
\hline Dairy products & 14 & 14 & 15 & 13 & 13 & 12 \\
\hline Vegetables, fruits and legumes & 24 & 21 & 21 & 32 & 27 & 27 \\
\hline Food preparation & 2 & 2 & 1 & 1 & 1 & 1 \\
\hline Food eaten out & 11 & 11 & 12 & 2 & 2 & 4 \\
\hline Other food & 11 & 13 & 12 & 11 & 14 & 12 \\
\hline Number of observations & 3911 & 4797 & 4442 & 665 & 823 & 814 \\
\hline \multicolumn{7}{|l|}{ Urban areas } \\
\hline Cereals & 13 & 13 & 15 & 21 & 20 & 23 \\
\hline Meat and fish & 23 & 23 & 21 & 22 & 22 & 18 \\
\hline Dairy products & 15 & 15 & 17 & 17 & 17 & 19 \\
\hline Vegetables, fruits and legumes & 16 & 15 & 16 & 21 & 20 & 20 \\
\hline Food preparation & 4 & 4 & 3 & 3 & 2 & 3 \\
\hline Food eaten out & 21 & 21 & 19 & 8 & 8 & 8 \\
\hline Other food & 8 & 9 & 8 & 9 & 9 & 9 \\
\hline Number of observations & 5739 & 7199 & 8709 & 1193 & 1491 & 1979 \\
\hline
\end{tabular}

Source: Prepared by the authors on the basis of the National Household Income and Expenditure Surveys (ENIGH) for 1992, 1994 and 1996.

Table 10 shows mean enrolment rates by region and sex of child, for the full sample of children as well as for children residing in households in the bottom quintile of the per capita expenditure distribution in each year. In general, urban rates are higher than rural rates, and male rates higher than female ones. The role of income seems to be stronger in urban areas, a finding that is consistent with the higher income elasticities for education expenses in urban areas referred to above. The gap between the full sample and the bottom quintile was larger in urban areas (20 percentage points for girls) than in rural ones (where the malefemale difference was never larger than 10 percentage points), and this gap increased in 1996. Male enrolment rates remained stable in both urban and rural areas, although there was a small decline after the crisis. According to table 10, the group that suffered most in terms of enrolment was girls in the bottom quintile in urban areas, whose enrolment rate dropped by 14 percentage points between 1994 and 1996, and was actually lower in 1996 (46\%) than at the beginning of the study period $(61 \%)$.

This result is confirmed within a multivariate framework. We stacked the three years of survey data and estimated a Probit equation for the probability of being enrolled in school during the survey. Control variables used in this exercise included age and sex of the child, education and sex of the household head, log per capita household expenditure, and survey year. We included a dummy variable equal to 1 if the child was a female from the bottom quintile in 1996. The coefficient of this variable was significant in urban areas, and when evaluated in terms of the means indicated that girls from the poorest families had enrolment rates that were seven percentage points lower than other children in the survey. In rural areas this coefficient was not significant. ${ }^{3}$

As in the case of the analysis conducted earlier for consumption patterns, we estimated Probit models for the determinants of enrolment separately for each year (and by region) in order to understand how these determinants may have changed following the economic crisis of 1995 . The control variables were those mentioned above (minus the survey year dummies), although for rural areas we had to aggregate the dummy variables for educational level of the head of household due to the small cell sizes.

The Probit marginal probabilities derived from the underlying coefficient estimates are presented in table 11 . We were particularly interested in the pattern of 'income effects' over time, as well as male-female differences. As was to be expected, the 'income effect'

\footnotetext{
3 Results available from the authors upon request.
} 
TABLE

\begin{tabular}{|c|c|c|c|}
\hline \multicolumn{4}{|c|}{ Mexico: Income effects for food ${ }^{a}$} \\
\hline & 1992 & 1994 & 1996 \\
\hline \multicolumn{4}{|l|}{ Rural areas } \\
\hline \multirow[t]{2}{*}{ Cereals } & -8.29 & -8.15 & -8.71 \\
\hline & $(20.72)$ & $(22.32)$ & $(22.04)$ \\
\hline \multirow[t]{2}{*}{ Meat and fish } & 5.90 & 4.48 & 5.38 \\
\hline & (14.37) & $(11.40)$ & $(13.71)$ \\
\hline \multirow[t]{2}{*}{ Dairy products } & -0.32 & -0.35 & 0.50 \\
\hline & $(0.89)$ & $(1.15)$ & $(1.57)$ \\
\hline \multirow[t]{2}{*}{ Vegetables. fruits and legumes } & -6.89 & -6.28 & -6.42 \\
\hline & $(17.35)$ & $(17.75)$ & $(17.93)$ \\
\hline \multirow[t]{2}{*}{ Food preparation } & 1.05 & 0.81 & 0.50 \\
\hline & $(5.19)$ & $(6.02)$ & $(3.48)$ \\
\hline \multirow[t]{2}{*}{ Food eaten out } & 9.60 & 10.84 & 9.38 \\
\hline & $(17.21)$ & $(18.89)$ & $(15.83)$ \\
\hline \multirow[t]{2}{*}{ Other food } & -1.06 & -1.36 & -0.62 \\
\hline & $(3.80)$ & $(4.51)$ & $(2.22)$ \\
\hline \multicolumn{4}{|l|}{ Urban areas } \\
\hline \multirow[t]{2}{*}{ Cereals } & -5.48 & -5.29 & -5.68 \\
\hline & $(27.51)$ & $(30.46)$ & $(31.24)$ \\
\hline \multirow[t]{2}{*}{ Meat and fish } & -0.42 & -0.59 & 0.34 \\
\hline & $(1.21)$ & $(1.92)$ & $(1.20)$ \\
\hline \multirow{2}{*}{ Dairy products } & -2.41 & -2.57 & -1.90 \\
\hline & $(10.25)$ & $(12.22)$ & $(9.22)$ \\
\hline \multirow[t]{2}{*}{ Vegetables. fruits and legumes } & -4.20 & -4.23 & -3.61 \\
\hline & $(16.76)$ & $(19.83)$ & (18.51) \\
\hline \multirow[t]{2}{*}{ Food preparation } & 0.81 & 066 & 0.59 \\
\hline & (4.12) & (4.14) & (3.85) \\
\hline \multirow[t]{2}{*}{ Food eaten out } & 12.46 & 12.54 & 10.60 \\
\hline & $(21.95)$ & (23.63) & $(22.43)$ \\
\hline \multirow[t]{2}{*}{ Other food } & -0.77 & -0.51 & -0.35 \\
\hline & $(4.23)$ & $(2.98)$ & $(2.25)$ \\
\hline
\end{tabular}

Source: Prepared by the authors on the basis of the National Household Income and Expenditure Surveys (ENIGH) for 1992,1994 and 1996. a The figures are coefficients of log per capita expenditure derived from Engel curve estimates using equation [1] in the text. t-statistics are shown in parentheses below the coefficients. Negative coefficients imply necessities, positive coefficients imply luxury items.

TABLE 10

Mexico: School enrolment rates for children aged 12-15, by year and sex (Percentages)

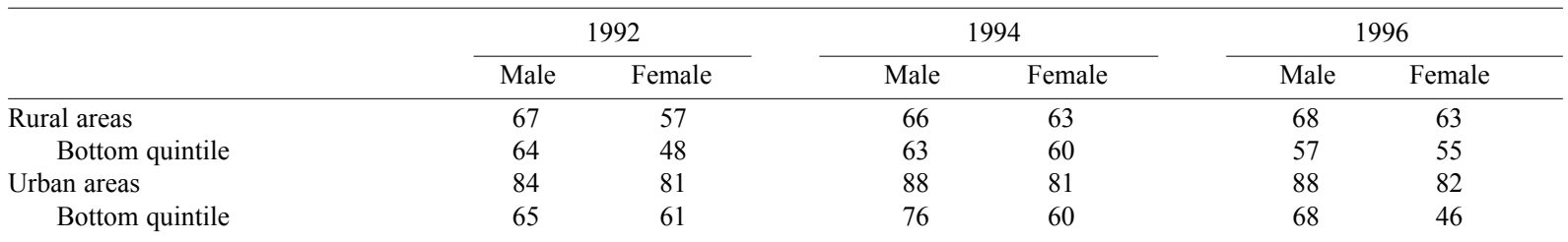

Source: Prepared by the authors on the basis of the National Household Income and Expenditure Surveys (ENIGH) for 1992, 1994 and 1996.

increased between 1994 and 1996, but the malefemale difference actually declined in rural areas immediately after the shock. This is probably due to boys being pulled out of school faster than girls during the crisis. It should also be noted that the 'returns' to head's education did not unambiguously increase in 1996 as we might have expected (the coefficient increased for primary but declined for secondary education), indicating that the decline in enrolment in
1996 did not depend on the level of education of the head of the household.

The income effects in urban areas were roughly the same as in rural areas, with an increase between 1994 and 1996. However the male 'premium' waslower in urban areas, and did not change between 1994 and 1996. An extremely interesting result is the decline in the 'returns' to the educational level of the head of household between 1994 and 1996. Hence, the

HOUSEHOLDS. POVERTY AND POLICY IN TIMES OF CRISIS. MEXICO. 1992-1996 • BENJAMIN DAVIS. SUDHANSHU HANDA AND HUMBERTO SOTO 
drops in enrolment in the aftermath of the shock were systematically related to the head's education, but in a way opposite to what we would expect. However, the rate of dropouts was related to overall household well- being (as measured by per capita expenditure), with poorer households more likely to have lower enrolment rates in 1996 compared with 1994.

TABLE 11

Mexico: Probit estimates of determinants of school enrolment of children between 12 and $15^{\text {a }}$

\begin{tabular}{|c|c|c|c|}
\hline & (1) & (2) & (3) \\
\hline & 1992 & 1994 & 1996 \\
\hline \multicolumn{4}{|l|}{ Rural areas } \\
\hline Log per capita expenditure & $\begin{array}{c}0.074 \\
(4.57)\end{array}$ & $\begin{array}{c}0.097 \\
(6.27)\end{array}$ & $\begin{array}{c}0.114 \\
(6.98)\end{array}$ \\
\hline \multirow[t]{2}{*}{ Male child } & 0.090 & 0.082 & 0.055 \\
\hline & $(4.22)$ & $(4.28)$ & (2.83) \\
\hline \multirow[t]{2}{*}{ Age 13} & -0.135 & -0.231 & -0.149 \\
\hline & $(4.33)$ & $(7.74)$ & $(4.92)$ \\
\hline \multirow[t]{2}{*}{ Age 14} & -0.282 & -0.354 & -0.274 \\
\hline & $(9.17)$ & (12.06) & (9.17) \\
\hline \multirow[t]{2}{*}{ Age 15} & -0.484 & -0.511 & -0.470 \\
\hline & (15.69) & (17.41) & $(15.47)$ \\
\hline \multirow[t]{2}{*}{ Head of household is female } & -0.036 & -0.082 & 0.008 \\
\hline & $(0.83)$ & (2.30) & $(0.21)$ \\
\hline \multirow[t]{2}{*}{ Head has incomplete primary education } & 0.055 & 0.020 & 0.034 \\
\hline & $(2.28)$ & $(0.94)$ & (1.44) \\
\hline \multirow[t]{2}{*}{ Head has complete primary education } & 0.152 & 0.076 & 0.111 \\
\hline & $(4.51)$ & $(2.49)$ & $(3.85)$ \\
\hline \multirow[t]{2}{*}{ Head has some secondary education } & 0.272 & 0.183 & 0.145 \\
\hline & $(5.45)$ & $(4.01)$ & $(3.41)$ \\
\hline Number of observations & 2226 & 2632 & 2417 \\
\hline \multicolumn{4}{|l|}{ Urban areas } \\
\hline \multirow[t]{2}{*}{ Log per capita expenditure } & 0.083 & 0.080 & 0.092 \\
\hline & $(7.46)$ & $(8.23)$ & (9.91) \\
\hline \multirow[t]{2}{*}{ Male child } & 0.034 & 0.048 & 0.048 \\
\hline & $(2.61)$ & $(4.09)$ & $(4.49)$ \\
\hline \multirow[t]{2}{*}{ Age 13} & -0.111 & -0.093 & 0.068 \\
\hline & $(4.44)$ & $(4.12)$ & (3.46) \\
\hline \multirow[t]{2}{*}{ Age 14} & -0.163 & -0.176 & -0.175 \\
\hline & $(6.54)$ & $(7.75)$ & $(8.48)$ \\
\hline \multirow[t]{2}{*}{ Age 15} & -0.343 & -0.339 & -0.272 \\
\hline & (13.00) & (13.33) & (12.33) \\
\hline \multirow[t]{2}{*}{ Head of household is female } & -0.063 & -0.029 & -0.022 \\
\hline & (3.11) & (1.67) & $(1.40)$ \\
\hline \multirow[t]{2}{*}{ Head has incomplete primary education } & 0.060 & 0.052 & 0.024 \\
\hline & (3.50) & (3.45) & (1.58) \\
\hline \multirow[t]{2}{*}{ Head has complete primary education } & 0.119 & 0.087 & 0.065 \\
\hline & (7.08) & (5.72) & $(4.23)$ \\
\hline \multirow[t]{2}{*}{ Head has some secondary education } & 0.118 & 0.121 & 0.080 \\
\hline & $(6.60)$ & (7.48) & $(4.84)$ \\
\hline \multirow[t]{2}{*}{ Head has some technical or vocational education } & 0.101 & 0.105 & 0.104 \\
\hline & $(4.16)$ & $(4.72)$ & $(5.02)$ \\
\hline \multirow[t]{2}{*}{ Head has some higher education } & 0.106 & 0.094 & 0.076 \\
\hline & $(4.14)$ & $(4.12)$ & $(3.43)$ \\
\hline Number of observations & 2658 & 3126 & 3554 \\
\hline
\end{tabular}

HOUSEHOLDS. POVERTY AND POLICY IN TIMES OF CRISIS. MEXICO. 1992-1996 - BENJAMIN DAVIS. SUDHANSHU HANDA AND HUMBERTO SOTO 


\section{Decomposition analysis}

The sharp fall in private consumption after the crisis came just after a period of economic expansion and strong growth in consumption. Within a longer-term perspective, the crisis also occurred after almost two decades of increasing human capital indicators such as educational attainment and health status, with corresponding declines in poverty rates. On the eve of the crisis, Mexico was clearly a very different society from what it had been 15 years before, in terms of the characteristics of its people and the structure of its economy, and yet almost overnight, private consumption and poverty fell back to levels of 15 years earlier. How did the evolution of the characteristics of Mexican households affect their capacity to absorb the economic shock of 1995 and, subsequently, to recover? In this section we use decomposition techniques to try and understand the role that structural changes related to long-term development (such as changes in the economy and human capital expansion) play in times of economic crisis, and the specific characteristics of households that were associated with the decline in welfare during the crisis.

For each of our three survey years, we relate household per capita consumption (in log form) to a set of household characteristics that we divide into seven groups:

$$
\begin{array}{r}
\log \mathrm{C}_{\mathrm{i}}= \\
\alpha+\beta_{1} * \text { MISC }+\beta_{2} * \mathrm{HE}+\beta_{3} * \mathrm{NHE}+\beta_{4} * \text { DEMO }+ \\
\beta_{5} * \text { EMPL }+\beta_{6} * \text { HOUSE }+\beta_{7} * \text { SECTOR }+\mathrm{u}_{\mathrm{i}}
\end{array}
$$
where:

MISC is a set of miscellaneous variables including $\log$ of family size, and the sex and age of the household head.

HE refers to the head's education, and is measured by a set of nine dummy variables indicating different levels of attained schooling.

NHE is the educational level of persons who are not heads of household, measured by the number of household members in four different schooling levels.

$\mathrm{DEMO}^{4}$ is the number of people in each of 10 different sex-specific age groups, plus the depend-

\footnotetext{
4 The number of males and females age 36-50 is actually not included in the regressions. because these numbers are highly correlated with the number of non-head adults in the four educational groups and the number of adults in the four employment states.
}

ency ratio of the household.

EMPL is the number of people employed respectively in agricultural wage labour, non-agricultur

al wage labour, self employed, and family employment.

HOUSE is captured by two dummy variables indicating whether the household owns or rents the house it lives in (other types of tenancy is the excluded category).

SECTOR is the sector of employment of the household head.

In equation [2], $\alpha$ and $\beta$ are the parameters to be estimated and $u_{i}$ is a random error term. Equation [2] is estimated for the households, separately by year and by urban and rural. Using urban and rural estimates from adjacent years, we decompose the change in consumption between the years into the proportion due to changes in the mean level of household characteristics, and the proportion due to differences in the 'returns' to these characteristics - the beta valuesstrictly according to the technique first pioneered by Ronald Oaxaca (1973 and 1998). Thus, for example, the decomposition for the period between 1992 and 1994, using 1992 as the base year, can be written as follows:

$$
\begin{aligned}
\Delta \text { Con }= & \text { Con }_{92}-\text { Con }_{94}=\left(C_{92}-C_{94}\right)+\mathrm{X}_{94}^{-} \\
& *\left(\hat{\beta}_{92}-\hat{\beta}_{94}\right)+\hat{\beta}_{92} *\left(\mathrm{X}_{92}-\mathrm{X}_{94}\right)
\end{aligned}
$$

where Con is (log of) per capita consumption, $C_{i}$ is the constant term in the regression for time period $i, X_{i}$ is the mean characteristics of households in time period $i$, and $\hat{\beta}_{i}$ is the coefficient vector for the regression from time period $i$. Equation [3] states that the change in consumption between time periods 0 and 1 can be decomposed into three components. The first is the difference in the estimated constant term between the two time periods. The second is the difference in coefficients (or betas) between the two time periods, or the 'returns' to household characteristics. The third is the difference in characteristics of households between the two periods, or the change in endowments. Since the 
values for the second period are subtracted from those for the initial period, an increase in consumption between the two periods will be reflected in a negative variation in consumption on the left hand side of equation [3]. As we shall see, this is what happened between 1992 and 1994. Likewise, a reduction in consumption will be reflected in a positive variation on the left hand side of equation [3], as occurred between 1994 and 1996.

Traditionally, this decomposition technique has been used to analyse male-female wage differentials; in that context, the portion of the wage differential that is due to differences in betas (or returns to characteristics) is a measure of the unequal treatment that men and women receive in the labour market. In the present study, we are comparing differences in consumption over time, hence differences in betas can be interpreted as differences in the environment between the two time periods, which lead to different returns to characteristics such as the education and sector of employment of the household head, for example. Furthermore, while we will refer to changes in the $X$ variables as changes in household characteristics, it is important to note that some of these changes are endogenous in the short run, as households may split or join in response to economic crisis, or household heads may change sectors of employment. The set of variables most likely to be exogenous in the short run is that describing the education of the household head and other adult household members, and since these are a direct measure of human capital, we will pay particular attention to the contribution of these variables to changes in overall household consumption.

Within this framework, we develop a number of hypotheses and prior assumptions regarding the sources and magnitude of consumption changes between 1992 and 1994 and 1994 and 1996. First, we expect that changes in betas will explain most of the changes in consumption, because the $X$ variables we use tend not to move drastically in the short run, and our time frame is only four years. However, because of the economic crisis, we expect that a larger proportion of the changes in consumption between 1994 and 1996 will be explained by changes in betas, compared with the 1992-1994 period.
Second, as mentioned earlier, the 1995 crisis was preceded by a lengthy period of expansion of human capital, as well as economic restructuring. If these changes in the characteristics of the Mexican population led to increases in consumption, then our decompositions should show changes in $X$ characteristics leading to increases in consumption over time, although the magnitude of these increases will be small since our time period is only four years.

In addition to these main hypotheses, the decomposition analysis permits us to see which group of household characteristics contributed the most to the decline (or rise) in consumption during the period under study. Finally, we can use the estimated coefficients for 1996, along with the $X$ characteristics for 1992 , to simulate and quantify the role of structural changes that are part of the long-term development process, as measured by the profile of the $X$ variables, in mitigating the adverse consequences of macroeconomic shocks.

Table 12 presents the results of the decomposition analysis for both rural and urban areas for the two adjacent time periods. ${ }^{5}$ In each case, consumption in the initial period is used as the base. Between 1992 and 1994 consumption increased, so the differences are negative, while between 1994 and 1996 consumption decreased, so the differences are positive. The results indicate that between 1992 and 1994, 95\% of the increase in consumption was due to change in returns to household characteristics (including the constant term) while 5\% were due to improvements in these characteristics. Between 1994 and 1996, however, changes in returns accounted for $106 \%$ of the decline in consumption, while improvement in $X$ characteristics actually led to a $6 \%$ increase in consumption. The results for urban areas tell the same story. Changes in betas accounted for a larger part of the change in consumption in the latter period (19941996) relative to the former period, and changes in $X$ characteristics actually led to improvements in households' ability to generate consumption, particularly between 1994 and 1996.

5 Results available from the authors upon request. 
TABLE 12

Mexico: Consumption variation decomposition

(Percentage variation)

\begin{tabular}{|c|c|c|c|c|}
\hline & \multicolumn{2}{|c|}{ 1992-1994 } & \multicolumn{2}{|c|}{ 1994-1996 } \\
\hline & $\beta$ & $\mathrm{X}$ & $\beta$ & $\mathrm{X}$ \\
\hline \multicolumn{5}{|l|}{ Rural areas } \\
\hline Other & -15.30 & $-1.29 *$ & -18.78 & $-0.53 *$ \\
\hline Head's education & -0.78 & $-0.20 *$ & 4.13 & $-2.60 *$ \\
\hline Non-head's education & 8.30 & $-0.89 *$ & 4.68 & $-1.27^{*}$ \\
\hline Demographic factors & -18.00 & $-2.44 *$ & 14.20 & $-0.39 *$ \\
\hline Employment & -15.90 & $-0.86^{*}$ & 8.40 & $-1.18^{*}$ \\
\hline Housing & 12.04 & $0.07 *$ & -1.30 & $0.34 *$ \\
\hline Sector & -11.38 & $0.21 *$ & -3.29 & $-0.22 *$ \\
\hline Constant & -53.62 & & 97.80 & \\
\hline Total & -94.64 & -5.40 & 105.84 & -5.85 \\
\hline \multicolumn{5}{|l|}{ Urban areas } \\
\hline Other & 17.31 & $0.00 *$ & 7.05 & $-1.40^{*}$ \\
\hline Head's education & 1.83 & $0.34 *$ & -1.14 & $-2.24^{*}$ \\
\hline Non-head's education & 10.50 & $0.60 *$ & -7.00 & $-0.75^{*}$ \\
\hline Demographic factors & -29.83 & $-0.57 *$ & 8.07 & $-0.34^{*}$ \\
\hline Employment & -20.36 & $-0.26^{*}$ & 9.19 & $0.33 *$ \\
\hline Housing & 11.67 & $0.21 *$ & -5.03 & $-0.08^{*}$ \\
\hline Sector & -5.28 & $0.01 *$ & 6.45 & $-0.07 *$ \\
\hline Constant & -86.02 & & 86.96 & \\
\hline Total & -100.18 & 0.33 & 104.55 & -4.55 \\
\hline
\end{tabular}

Source: Prepared by the authors on the basis of the National Household Income and Expenditure Surveys (ENIGH) for 1992, 1994 and 1996.

* Joint significance at $1 \%$ level.

TABLE 13

Mexico: Decomposition of consumption variation, by region

(Percentage variation)

\begin{tabular}{|c|c|c|c|c|c|c|c|c|c|c|c|c|}
\hline & \multicolumn{2}{|c|}{ North } & \multicolumn{2}{|c|}{$\begin{array}{l}\text { North } \\
\text { Pacific }\end{array}$} & \multicolumn{2}{|c|}{ Central } & \multicolumn{2}{|c|}{ Gulf } & \multicolumn{2}{|c|}{$\begin{array}{l}\text { Pacific } \\
\text { South }\end{array}$} & \multicolumn{2}{|c|}{$\begin{array}{l}\text { Urban } \\
\text { Metropolitan area }\end{array}$} \\
\hline & $\bar{\beta}$ & $\mathrm{X}$ & $\beta$ & $\mathrm{X}$ & $\beta$ & $\mathrm{X}$ & $\bar{\beta}$ & $\mathrm{X} \beta$ & $\bar{X}$ & $\beta$ & $\mathrm{X}$ & $\beta$ \\
\hline \multicolumn{13}{|l|}{$\overline{1992-1994}$} \\
\hline Other & 17,31 & $0,00^{*}$ & $-35,07$ & $0,44 *$ & 1,02 & $0,41^{*}$ & 30,05 & $-0,53^{*}$ & $-32,68$ & $-10,04 *$ & $-51,44$ & $-0,13^{*}$ \\
\hline Head's education & 1,83 & $0,34 *$ & $-7,89$ & $3,19^{*}$ & 0,02 & $0,29 *$ & $-2,01$ & $1,03^{*}$ & 7,28 & $-3,16^{*}$ & $-16,58$ & $-2,08$ \\
\hline Non-head's education & 10,50 & $0,60 *$ & 13,62 & $-1,78^{*}$ & 17,91 & $-1,22 *$ & $-17,14$ & $-0,72 *$ & 13,74 & $1,43 *$ & 14,35 & $-0,95 *$ \\
\hline Demographic factors & $-29,83$ & $0,57 *$ & $-7,43$ & $-1,10^{*}$ & $-31,48$ & $-1,01^{*}$ & $-27,16$ & $-0,94 *$ & $-11,09$ & $-1,84 *$ & $-0,43$ & $-0,40 *$ \\
\hline Employment & $-20,36$ & $0,26^{*}$ & 4,87 & $-0,07^{*}$ & $-26,43$ & $0,20^{*}$ & $-26,31$ & $1,18^{*}$ & $-10,52$ & $-0,36^{*}$ & $-3,35$ & 0,11 \\
\hline Housing & 11,67 & $0,21 *$ & 10,49 & $-0,27$ & 19,95 & $0,61 *$ & 29,30 & $1,52 *$ & 3,73 & $-0,15$ & 11,71 & $0,01 *$ \\
\hline Sector & $-5,28$ & $0,01 *$ & $-14,71$ & $0,63^{*}$ & $-0,85$ & $0,21^{*}$ & $-1,25$ & $1,95^{*}$ & $-10,24$ & $-2,93 *$ & 6,34 & $0,01^{*}$ \\
\hline Constant & $-86,02$ & & $-64,52$ & & $-79,61$ & & $-88,96$ & & $-43,08$ & & $-57,19$ & \\
\hline Total & $-100,18$ & 0,33 & $-100,64$ & 1,04 & $-99,47$ & $-0,51$ & $-103,48$ & 3,49 & $-82,86$ & $-17,05$ & $-96,59$ & $-3,43$ \\
\hline \multicolumn{13}{|l|}{ 1994-1996 } \\
\hline Other & $-23,81$ & $-0,84 *$ & $-24,08$ & $-0,41^{*}$ & $-5,67$ & $-2,12 *$ & $-22,92$ & $-2,91 *$ & 24,76 & $2,89 *$ & 1,10 & $-3,82 *$ \\
\hline Head's educatiol & 15,58 & $-3,93 *$ & 9,64 & $-4,17^{*}$ & $-0,83$ & $-2,92 *$ & 4,44 & $-8,18^{*}$ & $-5,79$ & $0,57 *$ & 9,33 & $0,42 *$ \\
\hline Non-head's education & 9,50 & $-0,40 *$ & 14,23 & $0,29 *$ & $-8,56$ & $-1,29 *$ & 4,91 & $-0,14 *$ & $-18,37$ & $-1,41 *$ & $-0,68$ & $-0,34$ \\
\hline Demographic factors & 14,45 & $0,18^{*}$ & 1,93 & $0,32 *$ & 13,90 & $-0,42 *$ & 34,99 & $-0,62 *$ & 13,84 & $1,90^{*}$ & $-4,81$ & $-0,97 *$ \\
\hline Employment & $-1,02$ & $-0,41 *$ & $-0,11$ & $0,12 *$ & 11,58 & $0,11 *$ & 30,67 & $0,61^{*}$ & 17,52 & $0,20^{*}$ & 5,98 & $-0,18$ \\
\hline Housing & 2,63 & $-0,25^{*}$ & $-4,34$ & $0,05^{*}$ & $-5,60$ & $-0,53^{*}$ & $-5,79$ & $-0,36^{*}$ & $-12,22$ & $0,45^{*}$ & $-5,57$ & $-0,13 *$ \\
\hline Sector & 10,29 & $-0,83 *$ & 15,40 & $0,37^{*}$ & 0,19 & $-0,42 *$ & 7,38 & $-2,02 *$ & 2,01 & $0,14 *$ & 0,23 & $-0,26$ \\
\hline Constant & 78,85 & & 90,76 & & 102,58 & & 59,94 & & 78,69 & & 99,69 & \\
\hline Total & 106,47 & $-6,48$ & 103,43 & $-3,43$ & 107,59 & $-7,59$ & 113,62 & $-13,62$ & 96,42 & 3,60 & 105,27 & $-5,28$ \\
\hline
\end{tabular}

Source: Prepared by the authors on the basis of the National Household Income and Expenditure Surveys (ENIGH) for 1992, 1994 and 1996.

* Joint significance at the $1 \%$ level

HOUSEHOLDS. POVERTY AND POLICY IN TIMES OF CRISIS. MEXICO. 1992-1996 • BENJAMIN DAVIS. SUDHANSHU HANDA AND HUMBERTO SOTO 
TABLE 14

Mexico: Simulated percentage changes in poverty indicators, using the 1992 household characteristics $^{\mathrm{a}}$

\begin{tabular}{lcc}
\hline Indicator & Rural areas & Urban areas \\
\hline Mean consumption & -14 & -8 \\
Headcount & 48 & 25 \\
Poverty gap & 45 & 33 \\
Squared poverty gap & 45 & 36
\end{tabular}

Source: Prepared by the authors on the basis of the National Household Income and Expenditure Surveys (ENIGH) for 1992,1994 and 1996.

a Simulations compare changes between $\beta_{96} \mathrm{X}_{96}$ and $\beta_{96} \mathrm{X}_{92}$.

The precise characteristics that contribute to positive consumption changes vary across time periods and between urban and rural areas. In rural areas, household demographics accounted for the majority of the increase in consumption among $X$ variables in the former period, while in the latter period the most important contributions came from the education of heads $(2.60 \%)$ and non-heads $(1.27 \%)$. In urban areas in the latter period, positive contributions to consumption came from heads' education $(2.24 \%)$ and the "miscellaneous" category (1.40\%), specifically household size. Of course, the majority of the change in consumption derives from changes in the returns to these characteristics. In the 1992-1994 period, large changes in the returns to type of employment and demographic composition significantly improved household consumption, and it was precisely the decline in the returns to these two characteristics that led to the significant decline in consumption during the crisis.

There is significant regional variation in levels of economic development in Mexico, and it is possible that different regions were affected differently by the 1995 crisis. To assess this hypothesis, we divided the country into six regions ${ }^{6}$ and repeated the decomposition analysis by region. The results are presented by time period in table 13 .

In every region without exception, the portion of the change in consumption due to changes in betas was larger in the crisis period (1994-1996). Furthermore, in this same period, every region except for the Pacific South showed changes in $X$ characteristics that served to increase consumption from 1994 to 1996, thus reducing or mitigating the negative impact of change in returns to these characteristics. These posi-

6 The regions were defined as follows: North (Coahuila. Chihuahua. Durango. Nuevo León. San Luis Potosí. Tamaulipas. Zacatecas). Pacific-North (Baja California Norte and Sur. Nayarit.Sinaloa. Sonora). Central (Aguascalientes. Guanajuato Hidalgo. Jalisco. Mexico. Michoacan. Morelos. Puebla. Queretaro. Tlaxcala). Gulf (Campeche. Quintana Roo. Tabasco. Veracruz tive endowment effects were particularly large in the Gulf (13.6\%) and Central regions (7.6\%). In both cases, the sources of improvement came from the education of the head and the miscellaneous category (particularly household size). With regard to returns, the pattern was somewhat mixed across regions, although fluctuations in the returns to employment type, demographic composition, and 'others' were key factors in the decline in consumption after the crisis. It is interesting to note that during the crisis period, the proportion of the welfare decline due to changes in returns was lowest in the Pacific South (96.4\%) and the Gulf (103.4\%), indicating that the impact of the crisis on the economic environment was least in these two areas relative to the rest of the country.

What would the impact of the crisis have been if Mexico had not realized any changes in structural characteristics between 1992 and 1996? To answer this question, we applied the characteristics of households in 1992 to the returns these characteristics provided in 1996, using the estimated coefficients from the 1996 regression function (hence we calculated $\widehat{\beta}_{96} \overline{\mathrm{X}}_{92}$ ). The resulting mean predicted level of consumption is $14 \%$ lower in rural areas than actual consumption reported in 1996. For urban areas the corresponding decline in mean consumption is $8 \%$. Table 14 presents these simulated changes, as well as those for a set of commonly used poverty indicators. In both regions, poverty rates would have been substantially higher in 1996 had there been no changes in the vector of $X$ characteristics of households. The impact of the improvement in these characteristics is especially large in rural areas. ${ }^{7}$

Another approach to measuring the influence of structural factors associated with economic development would be to simulate the impact of the crisis had

Yucatán). Pacific South (Colima. Guerrero. Oaxaca. Chiapas). and Metropolitan (Mexico City and Guadalajara).

7 A similar analysis was done using data from 1989 and 1996. with similar results. These are available from the authors upon request. 
it occurred in 1992. This amounts to comparing $\hat{\beta}_{96} \mathrm{X}_{92}$ not with actual consumption in 1996 , but with actual consumption in 1992. Using this approach, mean predicted consumption is $26 \%$ lower in rural areas and $36 \%$ lower in urban areas, compared to actu- al consumption in $1992 .{ }^{8}$ Using either approach, the results indicate that structural changes associated with the development process can play an important role in mitigating the adverse impact of economic crisis on household welfare.

\section{VI}

\section{The role of public programmes}

In this section we evaluate the degree to which two of Mexico's largest social programmes, PROCAMPO and PROGRESA, mitigated (or could have mitigated, in the case of PROGRESA) the adverse effects of the macroeconomic crisis in 1995. PROCAMPO is a programme providing a cash transfer to farmers who had cultivated any one of nine staple crops during the 1991-1993 agricultural seasons. The stated objective of this programme, which was established in 1994, is to compensate for the expected negative impact of NAFTA on the producers of these crops, and the programme is to be phased out after 15 years. Uniform payments are provided on a per-hectare basis and are decoupled from current land use. Payments were to remain constant in real terms for the first 10 years of the programme, then phase out over the remaining five years. In fact, however, the real value of payments fell $35 \%$ between the inception of the programme in 1994 and 1996. Only in 2001 did payments per hectare, as well as total PROCAMPO expenditures, reach the original 1994 levels in real terms. The per-hectare payment in 2002 was set at 875 Mexican pesos, or US\$ 90. PROCAMPO reaches almost three million producers each year. Of the almost 14 million hectares covered each year, approximately $79 \%$ are rainfed (Fox, 2002). The programme had a budget of US\$ 1.24 billion for fiscal year 2002, which represented $60 \%$ of the Ministry of Agriculture's total budget (PROCAMPO, 2002). Since the PROCAMPO benefits are distributed on a per-hectare basis, larger farms tend to get higher total transfers. Overall payments are regressively distributed; the $45 \%$ of producers with farms smaller that 5 hectares receive only $10 \%$ of total PROCAMPO transfers (SAGAR, 1998). Payments are progressively distributed on per-hectare basis, however, as they are uniform per hectare and are thus unrelated to yields achieved and whether households were selling basic crops before NAFTA.
PROGRESA, on the other hand, which is the Mexican government's premier poverty alleviation programme, provides cash transfers to very poor rural households provided they comply with a complex set of 'responsibilities'. These include ensuring that children are enrolled in school and maintain $85 \%$ attendance, that children and adults receive regular preventive health check-ups and vaccinations, and that mothers of beneficiary families attend a monthly health talk. In return for compliance, families receive cash payments depending on the number of children attending school and the level of schooling they have attained. For example, in 1998 children in grades 3-6 received from US\$ 7-12 depending on their level. Middle school students received US\$ 20-23 per month, with payments somewhat higher for girls relative to boys. In addition to these educational subsidies, each student received a package of school supplies twice a year, and the family received a monthly income supplement of approximately US\$10. Since 1997, these payments have increased in real terms by $47 \%$. As of the end of 1998 , over 1.9 million households were receiving PROGRESA benefits, requiring a total expenditure of approximately US\$ 900 million. When the Fox administration took office in 2001, PROGRESA changed its name to "Oportunidades" and expanded its operations to urban and semi-urban areas. By 2002, the PROGRESA budget had reached US\$ 1.9 billion, covering almost three million rural families and over 1.2 million urban and semi-urban families (Fox, 2002).

\footnotetext{
8 Once again. these results are available from the authors.
} 


\section{Direct Support Programme for Rural Areas (PROCAMPO)}

The 1996 round of household income and expenditure surverys (ENIGH) collected information on the monetary value of PROCAMPO benefits received by rural households. In the rural sample, $16 \%$ of households reported receiving PROCAMPO money, and among these recipients the mean level of benefits was 402 Mexican pesos per quarter, while actual monthly per capita expenditure among this same group was 604 Mexican pesos. Did PROCAMPO play an important role in mitigating the effect of the crisis among the rural population?

To answer this question, we first estimated the relationship between PROCAMPO benefits and household consumption by including the monetary value of PROCAMPO benefits in our consumption regression for 1996. The estimated coefficient of this variable was 0.0002 , with a t-value of 7 . Using these estimates, we predicted mean consumption as well as three poverty indicators (number of poor, poverty gap, and squared gap) using a relative poverty line set at the 25 th percentile of consumption in 1994 . We then set the value of PROCAMPO transfers to 0 and simulated the new values for these four measures of well-being. The percentage change in these indicators is reported in column (1) of table 15. Without PROCAMPO, mean consumption in 1996 would have been $1.5 \%$ lower, and all the poverty indicators would have been higher. For example, the number of poor would have been $5.1 \%$ higher, while the squared poverty gap, which gives more weight to the welfare of the poorest, would have increased by $5.7 \%$.

\begin{tabular}{|c|c|c|c|c|}
\hline \multirow{3}{*}{ Indicator } & \multicolumn{4}{|c|}{$\begin{array}{l}\text { Mexico: Simulated impact of social programmes on rural poverty indicators, } 1996 \\
\text { (Percentage variation) }\end{array}$} \\
\hline & \multirow{2}{*}{$\begin{array}{l}\text { If PROCAMPO } \\
\text { had not existed }\end{array}$} & \multicolumn{3}{|c|}{ If PROGRESA had existed } \\
\hline & & Phase $1 \& 2$ & Phase 1- 4 & All phases \\
\hline Mean consumption & -1.5 & 0.2 & 0.8 & 1.1 \\
\hline Headcount & 5.1 & -1.1 & -6.8 & -8.8 \\
\hline Poverty gap & 4.8 & -3.2 & -13.2 & -17.1 \\
\hline Squared poverty gap & 5.7 & -3.9 & -17.5 & -22.5 \\
\hline
\end{tabular}

Source: Prepared by the authors on the basis of the National Household Income and Expenditure Surveys (ENIGH) for 1992, 1994 and 1996.

\section{Education, Health and Food Programme (PROGRESA)}

Our analysis of the potential poverty-reducing impact of PROGRESA was more complicated, because PROGRESA only began distributing benefits at the end of 1997. In this case we ask the question "what would the impact on poverty have been had PROGRESA begun distributing benefits in 1996?".

We must go through several steps in order to answer this question. Since there is of course no information on PROGRESA benefits in the 1996 data, we first established the marginal propensity to consume out of cash income by including total per capita household income in our consumption equation for 1996. The coefficient of (log of) per capita income was 0.39 , with a t-value of 46. Based on this parameter, we then increased household cash income by the amount of benefits the household would have received had PROGRESA been functioning in 1996.
We decided which households should be assigned PROGRESA benefits by using PROGRESA's own targeting mechanism. First, each household in the rural ENIGH sample was designated as poor or non-poor, using the exact discriminant analysis model that PROGRESA uses to select beneficiary households. ${ }^{9}$ Next, we compared each locality in the ENIGH sample to the PROGRESA data base to see which localities were eventually incorporated into PROGRESA, and during which phase they were incorporated. Using this method we were able to identify which households in the 1996 ENIGH sample later became PROGRESA beneficiaries, and when. Based on this method, we found that $55 \%$ of rural households in the 1996 ENIGH were later incorporated into PROGRESA. Of these future beneficiaries, $15 \%$ were incorporated in the first two phases of PROGRESA, and 70\% were incorporated by the fourth phase.

\footnotetext{
9 See Skoufias. Davis. and de la Vega. 2001. for a description of this process.
} 
For each of these future beneficiary households, we calculated the potential transfer they would receive based on the age, sex, school enrolment status and grade attainment of their children. The monetary value of the school supply package (útiles) was also included in this assessment. Using these potential transfer amounts and the marginal propensity to consume out of cash income, we simulated percentage changes in welfare indicators based on varying assumptions on the extent of PROGRESA coverage in 1996. These results are shown in the last three columns of table 15 .

The first assumption we simulated was that by the end of 1996, only the first two phases of PROGRESA had been completed. This is probably the most realistic assumption, given the timing of the macroeconomic shock and the complexity involved in setting up PROGRESA. In this scenario, the number of poor would have decreased by $1.1 \%$, and the squared poverty gap would have decreased by $3.9 \%$. If phase four of PROGRESA had been completed by the end of 1996, the incidence of poverty would have declined by $6.8 \%$, the poverty gap by $13 \%$, and the squared poverty gap by $17.5 \%$. If PROGRESA had been completely implemented, the decline in poverty indicators would have been even greater $(8.8 \%$ in the case of incidence, $17 \%$ for the poverty gap, and $22.5 \%$ for the squared poverty gap). ${ }^{10}$ Although this last assumption is unrealistic for 1996, it allows juxtaposition of similar PROCAMPO/PROGRESA total budget figures, and thus a comparison of peso for peso poverty impact. It also provides us with an idea of the extent to which the current PROGRESA programme would serve as a safety net in the case of a macroeconomic crisis such as that of 1995 . Note also that PROGRESA has a larger impact than PROCAMPO on the poverty gap and the severity of poverty. This is because PROGRESA is targeted towards the poorest rural families.

\section{VII}

\section{Conclusions and policy implications}

In this paper we have explored the interrelated factors of policy, structural change and household behaviour around the period of the severe economic crisis of 1995 in Mexico. The results stress the importance of both medium-term development goals and short-term social safety nets in mitigating the negative impact of a macroeconomic shock. We find first a significant and expected response on the part of poor households to a fall in income. Households increased the share of food consumption, and within food consumption, of cereals and fruits and vegetables. Differences in the composition of the food basket between urban and rural households have implications for food price policy. The rural basket is dominated by cereals and vegetables, fruits and legumes, while the urban basket is dominated by meats and fish, and food eaten out. However, the food consumption patterns of the urban poorest (bottom quintile) resemble that of rural households, but not of poor rural households.

Second, we find that the aftermath of the economic crisis led to lower enrolment rates, particularly for poor urban girls. These changes are worrying in that they represent possible long-term costs of the crisis. The fall in enrolment rates was related to house- hold income for both urban and rural households. Higher levels of household income increased the probability of enrolment.

Third, on the eve of the 1995 peso crisis, Mexico had experienced five years of growth, accompanied by economic restructuring, increases in social indicators, and declines in poverty. The decomposition analysis presented in this paper suggests that changes in the characteristics of the economy and of households between 1992 and 1996 helped to mitigate the impact of the crisis. Simulations show that poverty would have been significantly higher during the crisis without these changes. These results imply that economic strategies focusing purely on growth, without ensuring medium-term development (such as access to education), can be very costly, especially in times of macroeconomic crisis.

Finally, the results from this study also provide some lessons on programme design and impact.

\footnotetext{
10 The actual levels of the predicted poverty gap and squared poverty gap are low in 1996, since the predictions using the ordinary least squares method over-predict smaller values of the dependent variable and under-predict larger values.
} 
Mexico's PROGRESA programme, although designed to stimulate investment in the long-run human capital of the poorest, could play an important safety net function during a macro economic crisis. Simulations show that had PROGRESA been operating in 1996, the severity of poverty and the squared poverty gap would have been significantly lower than the levels registered in that year. This is an important result for other Latin American countries considering or imple- menting demand- side interventions to raise the human capital of the very poorest, such as Nicaragua, Honduras, and Brazil. However, the key to success will depend on accurate targeting mechanisms that ensure that such programmes really do favour the very poorest.

Bibliography

Banco de México (1999): http://www.banxico.org.mx, November. CONAPO (Consejo Nacional de Población) (1997): La situación demográfica de México, Mexico City.

Deaton, A. and J. Muellbauer (1996): Economics and Consumer Behavior, Cambridge, Cambridge Univer-sity Press.

ECLAC (Economic Commission for Latin America and the Caribbean) (2002): Social Panorama of Latin America, 20012002, LC/G.2183-P, Santiago, Chile, October. United Nations publication, Sales No. E.02.II.G.65.

Fox, V. (2002): Informe de gobierno, 2002, Mexico City, September. http://informe.presidencia.gob.mx/Informes/2002Fox2/website/cfm/index.cfm

Hernández-Laos, E. (1990): Medición de la intensidad de la pobreza y de la pobreza extrema en México, Investigación económica, vol. 49, No. 191, Mexico, City, National Autonomous University of Mexico.

INEGI (Nacional Institute of Statistics, Geography and Information) (1999): http://www.inegi.gob.mx/inegi/default.asp, November.

Lusting, N. and M. Székely (1998): México: evolución económica, pobreza, y desigualdad, in E. Ganuza, L. Taylor and S. Morley (eds.), Política macroeconómica y pobreza en América Latina y el Caribe, Madrid, Mundi-Prensa.
Oaxaca, R. (1973): Male-female wage differentials in urban labor markets, International Economic Review, vol. 14, Philadelphia, University of Pennsylvania. (1998): On discrimination and the decomposition of wage differentials, Journal of Econometrics, vol. 61, No. 3, Amsterdam, Elsevier Science.

PROCAMPO (Programa de Apoyos Directos al Campo) (2002): Resultados principales del 3er trimestre del año fiscal 2002, October [www.procampo.gob.mx].

Programa Nacional de Acción a favor de la Infancia, 1995-2000 (1998): Evaluación 1998, Mexico City, Comisión Nacional de Acción a favor de la Infancia.

SAGAR (Secretaría de Agricultura, Ganadería y Desarrollo Rural) (1998): PROCAMPO, 1994-1998, Claridades agropecuarias, No. 64, Mexico City, December.

Skoufias, E., B. Davis and S. de la Vega (2001): Targeting the poor in Mexico: an evaluation of the selection of households into PROGRESA, World Development, vol. 29, No. 10, Amsterdam, Elsevier Science.

Székely, M. (1998): The Economics of Poverty, Inequality, and Wealth Accumulation in Mexico, London, Macmillan/St. Antony's College. 